\title{
THE IMPACT OF COVID-19 PANDEMIC ON IMPROVING THE LEGAL REGULATION OF PROTECTION OF HUMAN RIGHT TO HEALTH
}

DOI: 10.36740/WLek202012211

\author{
Oleh M. Omelchuk, Inna V. Shevchuk, Anna V. Danilova \\ LEONID YUZKOV KHMELNYTSKYI UNIVERSITY OF MANAGEMENT AND LAW, KHMELNYTSKYI, UKRAINE
}

\begin{abstract}
The aim: Theoretical and methodological substantiation of the impact of COVID-19 on the implementation of state policy on the protection of human right to health in terms of improving the legal framework in the field of demographic security.

Materials and methods: The main research materials are the norms of the International Covenant on Economic, Social and Cultural Rights, the Conventions for the Protection of Human Rights and Fundamental Freedoms and the legal framework of the countries that have adopted temporary quarantine measures. This research is based on empirical and analytical data from WHO, Bloomberg's financial information provider. During the research, the following methods have been used: statistical, system-structural analysis, content-analysis, comparison, grouping and forecasting.

Conclusions: Under the conditions of pandemic, attention should be paid to strengthening both administrative and criminal liability for violating quarantine, which will serve as a prerequisite for improving the legal mechanism of combating threats to the country's demographic security. The protection of the right to health requires the state to create conditions to prevent the risk of occupational diseases among health care workers and others involved in the response to COVID-19.
\end{abstract}

KEY WORDS: global health, demographic sphere, state policy, health care

Wiad Lek. 2020;73(12 p. II):2768-2772

\section{INTRODUCTION}

The determining factor of stable socio-economic development of the state is demographic security, and demographic processes are the prerequisite and the result of qualitative and quantitative changes in the demographic situation in the country. Therefore, the preservation of human resources, as a carrier of the intellectual potential of the nation, requires special attention and, today, acquires not only domestic but also geopolitical significance. It should be noted that the state of demographic security of the country is influenced by external factors, which due to the destructive impact on the demographic system can affect the political, economic, social and spiritual spheres of society, the level of socio-economic development of the state. Demographic security is currently the focus of the issue of depopulation of inhabitants, especially under the conditions of active phase of the COVID-19 pandemic, which requires demographic security as an adaptive system, improvement of state demographic policy in order to respond in a timely manner and counter threats to demographic security.

An important direction in struggle against the COVID-19 pandemic is a proper and timely legal response. The sphere of health care today, more than ever before, requires improvement of the existing and creation of the new strong legal framework, the legal principles of which would meet the international obligations of the state to respond to public health threats.
Scientists such as I. Azemsha, Ye. Podorozhnii, V. Lordkipanidze, A. Malnar, D. Malnar made an invaluable contribution to the study of the influence of the "responsibility" category on the state of demographic processes and, accordingly, the condition of the state's demographic security. However, the scientific work of the scientists focuses on the study of certain aspects of the studied phenomena, while the issue of improving the normative-legal providing of demographic security of the country under the conditions of pandemic becomes actual, namely improving the legal regulation of liability for violating the rules and norms of human quarantine. Thus, the relevance of the research topic determined the aim and the objectives of the study.

\section{THE AIM}

Theoretical and methodological justification of COVID-19 impact on the implementation of state policy to ensure the demographic security of the state and the protection of human right to health under the conditions of relevant legal framework improving.

To achieve this aim the following tasks should be solved:

1) to determine the main sources of threats to demographic security under the conditions of COVID-19 pandemic, to determine the main aspects of state policy improving during the pandemic;

2) to study foreign experience in legal regulation of liability for violation of quarantine conditions and the specifics of determining fines; 
3) to suggest the approach to increase the response to the negative consequences of the pandemic and to propose key recommendations for counteracting the threats of the pandemic consequences to demographic sphere.

\section{MATERIALS AND METHODS}

The main research materials are the norms of the International Covenant on Economic, Social and Cultural Rights, the Convention for the Protection of Human Rights and Fundamental Freedoms and the legal framework of the countries that have adopted temporary quarantine measures. This research is based on empirical and analytical data from the WHO, Bloomberg's financial information provider, in particular on the number of patients in WHO regions, as well as the amount of fines for violating quarantine norms. In this research we used a number of research methods, in particular: the method of processing statistical data to analyze the number of patients in the world; the method of system-structural analysis to study the peculiarities of the application of measures to counteract and prevent possible threats to the demographic sphere; content analysis, method of comparison for the study of state policy of foreign countries related to ensuring the state's demographic security under the conditions of quarantine and the specifics of setting the amount of fine for violation of quarantine; grouping and forecasting to substantiate the conceptual framework of legal regulation of the issue of liability for violations of quarantine conditions and improving the mechanism of protection of human right to health.

\section{REVIEW AND DISCUSSION}

Taking into account the importance of the demographic situation, it should be noted that such negative processes of declining birth rates and increasing aging of population can threaten the passage of demographic processes and demographic security in general $[1, \mathrm{p} .115]$.

Studies of the security aspect indicate the priority of demographic development of the state as a determining factor of security, which can serve as an indicator of the security sector and possible changes [2, p. 59]. The prerequisite for these steps should be clarifying the contextual filling of the category "responsibility". Considering legal responsibility as an independent phenomenon, it is advisable to emphasize that it comes from social responsibility, acting as a separate, unique manifestation [3, p. 7].

The opinion of I.B. Azemsha, who emphasizes the social communicative nature of responsibility, which arises when human behavior is regulated by social norms and carries social significance is essential. In this case, the implementation of social norms is a social value phenomenon, and the actions that violate the rules that are socially significant are considered unacceptable and those that lead to the rupture of social communication causing negative reaction of society in the form of social responsibility [4, p. 54]. Thus, responsibility has a preventive effect, it is a mechanism for stopping illegal behavior and a measure to protect society. Establishing strategic priorities for the development of the demographic sphere will undoubtedly have a significant impact on the development of both society and the state. Therefore, special significance should be given to the process of formation and implementation of effective balanced state demographic policy, especially under the conditions of pandemic. Such policy will improve demographic processes in the country and prevent negative consequences of internal and external threats to demographic security of the country in the global transformational context. Among the main aspects to pay attention to when analyzing the state of demographic security of the country, the following are worth noting:

1) population of the country (population density, proportion of inhabitants of a particular region in the general structure of the population, depopulation, etc.);

2) the structure of population (disparities in gender and age composition of the population, imbalance of rejuvenation and population aging processes);

3) the reproduction of population (life expectancy, the ratio of reproduction and mortality of population);

4) the natural movement of population (natural increase (decline) of the population, birth rate and mortality, number of marriages and divorces);

5) the migration processes (intensification of urbanization processes, disproportions of the territorial location of the population, migratory population growth, growth of amounts of illegal migration).

The active spread of the COVID-19 coronavirus pandemic has caused great concern, forcing the countries to adapt to the new realities. As of August 17, 2020, 21,549,706 confirmed cases of COVID-19 were registered, including 767,158 deaths [5]. According to the World Health Organization, the leading region in the number of confirmed cases of COVID-19 is the United States $(11,561,554$ cases), followed by Europe (3,754,649 cases), Southeast Asia ( $3,103,018$ cases), Eastern Mediterranean (1,737,027 cases), Africa ( 945,165 cases), western Pacific (414,606 cases) [5].

The virus is known to be aerosol-transmitted, so social distancing can prevent infection through respiratory drops when sneezing and coughing. Scientific studies suggest that the corona type of SARS-CoV virus can persist on the surface for up to 96 hours [6], while other types of virus - up to 9 days, and the incubation period can last up to 24 days [7], although the basis for conclusions is the state of patients after two weeks of the disease. It should be noted that SARS-CoV-2 infection significantly worsens the course of concomitant chronic diseases, especially diabetes and cardiovascular disease. Therefore, the key recommendation in the struggle against the pandemic is the prohibition of mass gatherings, social distance and timely consultation with a doctor when first symptoms of the disease appear.

The scale and severity of the COVID-19 pandemic is clearly growing to the level of the threat to society as a whole. In a number of countries, the outbreak has demonstrated shortcomings in health and social protection systems, making it difficult to protect at-risk groups and reduce disease transmission. In responding to this crisis, governments must give priority to human rights, including the right to health. 
Responding to the challenges of COVID-19, countries are trying to create conditions that would contain the spread of the pandemic. However, each country responds to the same challenges with different measures and deadlines, which ultimately leads to differences in the epidemiological situation. Nevertheless, it is also necessary to take into account that countries have different reporting standards, different approaches to testing. It takes time to properly assess the effectiveness of the implemented measures, so the most informative is the negative experience of regions with early outbreaks - China, South Korea, Singapore and others.

China's approach included strict quarantine; strict restrictions on international and domestic travel; use of QR-health codes for permits to movement around the city; frequent household and street disinfection; testing, admission and treatment of all patients; isolation of suspicious cases, rapid construction of specialized hospitals for the treatment of patients with coronavirus.

In South Korea free and mass testing was conducted for people with symptoms, with suspicious contacts and for travelers. Education was not conducted in schools, it was recommended to work remotely, and large gatherings of people were prohibited.

Taiwanese authorities have been actively identifying patients with severe respiratory symptoms (based on information from the National Health Insurance database), and citizens have been encouraged to report suspicious symptoms or hotline numbers. The authorities monitored infected people and mapped cases. Contact persons were inspected on a large scale, from simple communication with the patient to the inspection of internal surveillance cameras. The location and observance of the rules of self-isolation of people with coronavirus through personal phones were monitored.

Although these early and decisive measures did not eradicate the virus, they helped to delay its spread over time relieving the capacity of the health care system, thus guaranteeing everyone the right to health established by the International Covenant on Economic, Social and Cultural Rights, which stipulates that states must create conditions that provide everyone with medical care and medical assistance in the event of illness [8].

The tendency to increase the number of patients has led to the increase in state budget expenditures to overcome the coronavirus epidemic and eliminate the consequences. Thus, as of April 9, 2020, budget measures totaling more than 8 trillion US dollars have been implemented worldwide [9].

Overcoming the negative consequences of the pandemic requires the implementation of appropriate measures and their realization through the state policy. Thus, a number of countries and health care providers are making concerted, joint efforts to combat the coronavirus. The European Commission has launched the global online donor conference, "Coronavirus Global Response", to combat COVID-19 in response to the World Health Organization's call for cooperation to raise funds to jointly develop and widely implement effective diagnostic, treatment and vac- cination tools against the coronavirus, whose participants managed to raise 7.4 billion euros [10].

To reduce losses and overcome the spread of infectious disease, it is extremely important to work ahead, introducing additional unprecedented protection measures, including forced quarantine, curfews, restrictions and / or blocking opportunities to travel, engage in economic activities, lead active social life and more. The Convention for the Protection of Human Rights and Fundamental Freedoms recognizes that in the context of public danger that threatens the life of the nation, including serious threats to public health, such restrictions of rights may be justified [11]. The International Covenant on Economic, Social and Cultural Rights guarantees everyone the right to the highest attainable standard of health and obliges states to take all necessary measures for the prevention, treatment and control of epidemic diseases [12]. The Syracuse Principles determine that in the event of a conflict between human rights and public health needs, states may restrict rights. However, in any case, such actions must be necessary to achieve legitimate goals, based on scientific evidence, to have limited period to be revised [13].

The study of foreign experience in solving this problem revealed that the pandemic contributed to the increase in fines for violating quarantine rules.

For example, in Poland, the amount of the fine imposed by the sanitary-epidemiological service for violating quarantine reaches PLN 30,000. In Latvia, the fine for violating quarantine is 350 euros, but if such violations are found serious or prove the intentional infection of others, the violator faces 3 years of imprisonment [15]. In Saudi Arabia, violation of quarantine is punishable by a fine of $\$ 53,300$ or two years imprisonment [14].

In some countries, criminal liability was immediately imposed for those who did not comply with coronavirus control instructions. For example, in Romania, for ignoring the quarantine requirements a person can be imprisoned for 3 years, for infecting others - up to 5 years, for failure to take measures to combat the epidemic that led to death - up to 15 years of imprisonment [15]. The largest scope of offenses is a public appearance without a protective mask, which is a very serious disregard for one of the basic rules of anti-epidemic safety. The study of the situation regarding quarantine restrictions in the Federal Republic of Germany shows the possibility of slowing down the spread of the virus by $40 \%$ due to the establishment of requirements for wearing a protective mask. The basis of this hypothesis was the experience of the German city of Jena, in which the mask regime was among the first to be introduced. After 20 days, the number of new cases in the city decreased by $25 \%$, and later approached almost zero. The results of the study varied depending on the region, but there was a noticeable tendency to reduce the number of reported cases of infection by $2.3-13 \%$ within 10 days after wearing the mask became mandatory [16]. Therefore, the use of medical masks, provided they are used properly, is an effective method of preventing the spread of coronavirus.

Equally important task for the states in the context of 
ensuring the right to health is to minimize the risk of occupational diseases among healthcare workers and others involved in responding to COVID-19. In the first place, this should be done by providing these people with appropriate protective equipment. In addition to the risk of COVID-19 infection at work, they are forced to overwork, as a result of which they may experience psychological stress and fatigue [17]. Therefore, special training and psychological assistance should be provided for such persons.

The World Health Organization has established strategic and technical advisory group of the World Health Organization on infectious hazards, the main activity of which today includes regular monitoring and risk assessment of the COVID-19 pandemic, as well as the development of practical recommendations to the World Health Organization on measures to counteract and prevent emergencies in healthcare. The active spread of the pandemic and the growing number of patients requires use of self-defense measures. Thus, the World Health Organization's strategic and technical advisory group has developed a number of recommendations to reduce the rate of infection transmission:

1) States should ensure preparedness and strengthen response measures, taking into account possible scenarios for the spread of the virus.

2) In order to strengthen preventive measures, it is necessary to consider the possibility of combining protection measures, in particular: preparation of the health care system for a possible increase in the number of diseases, control and prevention of infections in medical institutions, informing population, active promotion of personal hygiene under the conditions of pandemic.

3 ) In countries where COVID-19 has not yet been identified or has been detected in a small number of cases, epidemiological surveillance activities should be intensified in order to detect cases of illness in a timely manner and apply preventive measures for further spread among the population. Additional necessary measure to combat the spread of infection is social distancing, which should be observed both indoors and outdoors.

Countries in the $\mathrm{WHO}$ region should receive all the necessary financial and technical assistance, including from the World Bank, in particular from the Pandemic Emergency Fund, etc. [18].

4) Scientific researches on gaps in the COVID-19 pandemic study should be strengthened and foreign experience in combating and counteracting the spread of the virus should be implemented.

Taking into account rapid spread of the disease and increase in budget expenditures to combat COVID-19 among members of the world community, we propose to implement best practices in legal enforcement of the COVID-19 pandemic, increasing the responsibility for violating quarantine rules:

administrative liability - by increasing the amount of fines; criminal liability - by abolishing the possibility of execution of a penalty in the form of a fine, leaving in the sanction of the article only sanctions in the form of arrest, restriction or imprisonment.

\section{CONCLUSIONS}

Revenues to the state budget from the payment of fines for violating quarantine norms should be used to finance monetary compensation to those involved in the struggle against the pandemic, in order to form effective state demographic policy to respond to today's challenges.

We emphasize that the proposed aspects of responsibility can serve as a practical recommendation for the formation of foreign countries regulatory framework.

1) Under the conditions of pandemic, attention should be paid to strengthening both administrative and criminal liability for violating quarantine, which will serve as a prerequisite for improving the legal mechanism for countering threats to the country's demographic security by responding to challenges and dangers, creating conditions for socio-economic development and quality progress of society.

2) The protection of the right to health requires states to create conditions to prevent risk of occupational diseases among healthcare workers and other persons involved in response to COVID-19.

3) All countries must commit themselves to quickly respond to challenges and take all necessary health measures, strive to provide adequate and enough funding to contain the virus and protect people. Only global, coordinated, international cooperation can minimize the negative effects of the pandemic.

\section{REFERENCES}

1. LordkipanidzeV. Demographic Development and Demographic Security in Georgia. Bulletin of the Georgian National Academy of sciences. 2016;10 (1):112-117.

2. Malnar D., Malnar A. Demographic Security Trends in South eastern Europe. CIRR. 2015; XXI (73): 57-87.

3. Podorozhniy E. Yu. Teoretychni pidkhody do vyznachennya ponyattya «yurydychna vidpovidalnist» [Theoretical approaches to the definition of "legal liability"].Bulletin of Kharkiv National University of Internal Affairs.2014;3(66):6-15. (Ua).

4. Azemsha I. B. Yurydychna vidpovidalnist: suchasni pohlyady, dyskusiyi ta kontseptsiyi [Legal responsibility: modern views, discussions and concepts]. Journal of Kyiv University of Law.2010; 3: 54-57 (Ua).

5. Website World Health Organization. Available from: https://covid19. who.int. [reviewed 2020.09.12].

6. KramerA., Schwebkel., KampfG.How long do nosocomial pathogens persist on inanimate surfaces? A systematic review. BMC InfectDis. 2006; 6: 130 .

7. HuangC. , WangY., LiX., RenL. , ZhaoJ., HuY., etal.Clinical features of patients infected with 2019 novel coronavirus in Wuhan, China. Lancet. 2020; 395 : 497-506.

8. Website of the Office of the United Nation High Commissioner for Human Rights Available from: https://www.ohchr.org/en/professionalinterest/ pages/cescr.aspx [reviewed 2020.09.12].

9. Website of the National Institute for Strategic Studies. Available from: https://niss.gov.ua/sites/default/files/2020-04/svitova-ekonomika-tapandemiya.pdf [reviewed 2020.09.12] (Ua).

10. Website of European Commission Available from: https://ec.europa. eu/commission/presscorner/detail/en/ip_20_797 [reviewed 2020.09.12] (Ua). 
11. Convention for the Protection of Human Rights and Fundamental Freedoms. Available from: https://zakon.rada.gov.ua/laws/ show/995_004\#Text [reviewed 2020.09.12] (Ua).

12. Website of the Office of the United Nations High Commissioner for Human Rights. Available from: https://www.ohchr.org/en/ professionalinterest/pages/cescr.aspx [reviewed 2020.09.12].

13. Syracuse Principles for the Interpretation of Restrictions on Derogations from the Provisions of the International Covenant on Civil and Political Rights. Available from: http://www1.umn.edu/humanrts/instree/ siracusaprinciples.html. [reviewed 2020.09.12].

14. Website Bloomberg. Available from: https://www.bloomberg.com/ news/articles/2020-05-05/saudi-arabia-will-enforce-covid-19lockdown-with-tough-penalties [reviewed 2020.09.12].

15. Website of the National Institute for Strategic Studies : Available from: https://niss.gov.ua/sites/default/files/2020-03/site-2403-2.pdf [reviewed 2020.09.12] (Ua).

16. MitzeT., Kosfeld R., Rode J., Wilde K.FaceMasksConsiderablyReduce COVID-19 Casesin Germany: A Synthetic Control Method Approach. IZA DP. 2020;13319. Available from: http://ftp.iza.org/dp13319.pdf [reviewed 2020.09.12].

17. WHO, Coronavirus disease (COVID-19) outbreak: Rights, roles and responsibilities of health workers, including key considerations for occupational safety and health, Available from: http://www.who. int/docs/default-source/coronaviruse/who-rights-rolesrespon-hwcovid-19.pdf?sfvrsn=bcabd401_0 [reviewed 2020.09.12].

18. WHO New Coronavirus 2019 (2019 nCoV): Strategic Preparedness and Response Plan Available from: https://www.who.int/docs/defaultsource/coronaviruse/srp-04022020.pdf [reviewed 2020.09.12].
The article was performed within the research work of Leonid Yuzkov Khmelnytskyi University of Management and Law on the topic "Administrative and legal principles of sustainable development of Ukraine as a European state» (SR № 0108U008927).

\section{ORCID and contributions:}

Oleh M. Omelchuk: 0000-0003-4057-380X D,E

Inna V. Shevchuk: 0000-0001-9062-8907 A, F

Anna V. Danilova: 0000-0003-0744-5523 ${ }^{\text {B,C }}$

\section{Conflict of interest}

The Authors declare no conflict of interest.

\section{CORRESPONDING AUTHOR} Oleh M. Omelchuk

Leonid Yuzkov Khmelnytskyi University of Management and Law, st. Heroiv Maidan, 8, 29000, Khmelnytskyi, Ukraine e-mail: olegnik97@gmail.com

Received: 27.08 .2020

Accepted: 25.11 .2020

A - Work concept and design, B - Data collection and analysis, C - Responsibility for statistical analysis, D-Writing the article, $\mathbf{E}$-Critical review, $\mathbf{F}$ - Final approval of the article 